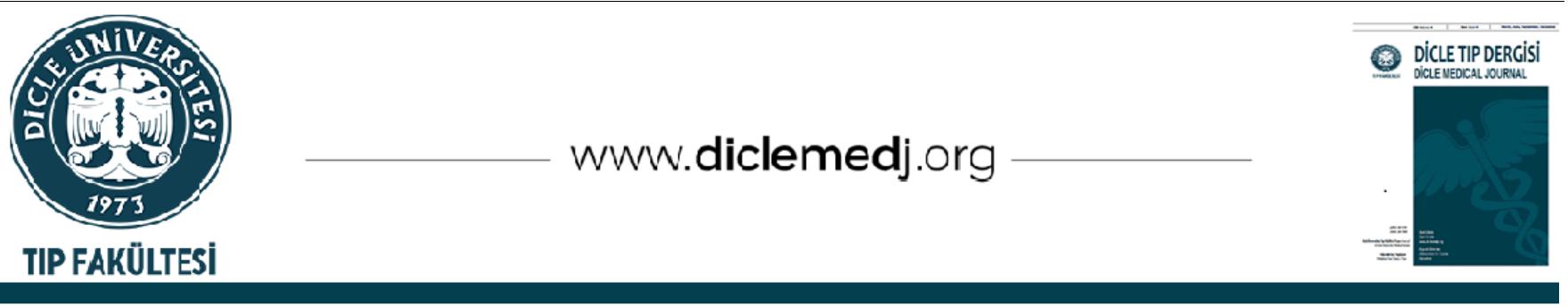

\title{
Pandemi Döneminde COVID-19 Kliniği ile Başvuran ve Tesadüfen Tespit Edilen AIDS Olgusu
}

\author{
Fethiye Akgül ${ }^{i}{ }_{1}$, Mustafa Kemal Çelen ${ }^{i}{ }_{2}$ \\ 1 Batman Bölge Devlet Hastanesi, Enfeksiyon Hastalıkları ve Klinik Mikrobiyoloji Kliniği, Batman, Türkiye \\ 2 Dicle Üniversitesi Tıp Fakültesi Enfeksiyon Hastalıkları ve Klinik Mikrobiyoloji ABD, Diyarbakır, Türkiye \\ Geliş: 13.06.2020; Revizyon: 23.11.2020; Kabul Tarihi: 24.11.2020
}

\section{$\ddot{0} \mathbf{z}$}

Pneumocystis pnömonisi (PCP), Pneumocystis jirovecii mantarının neden olduğu ciddi bir fırsatçı enfeksiyondur. Bununla birlikte, 31 Aralık 2019'da Çin'in Wuhan eyaletinde etiyolojisi bilinmeyen pnömoni vakalarının tanınmasını takiben, hastalarda şiddetli akut solunum sendromu koronavirüs 2019'un (SARS-CoV-2) saptanması, yeni bir koronavirüs türünü ortaya çıkarmıştır. Bu virüsün neden olduğu hastalık daha sonra Dünya Sağlık Örgütü tarafından COVID-19 (Coronavirus hastalığı 2019) olarak adlandırılmıștır. Klinik pratikte, her iki enfeksiyonda (PCP ve COVID-19) da ateș, nefes darlığı ve bilateral akciğer parankiminde pnömonik infiltrasyonla uyumlu radyolojik bulgularla karşılaşmaktayız. 11 Mayıs 2020 itibariyle, COVID-19 salgını beş kıtada 198 ülkeyi ve yaklaşık 4.239.167 kişiyi etkilemiştir. Dünya Sağlık Örgütü 20 Mart 2020 tarihinde pandemi ilan etmiştir.

Pandemi döneminde ateş ve solunum sıkıntısı ile gelen her hastada öncelikle COVID-19 düşünülmeli ve daha ileri tetkikler yapılmalıdır. 22 yaşında erkek hasta bu dönemde 2 gündür olan ateş ve solunum sıkıntısı şikayeti ile başvurdu. Fizik muayenesinde ateşi $38,3^{\circ} \mathrm{C}$ idi ve akciğer oskültasyonunda ince bilateral ralleri vardı. Laboratuvar testlerinde ise kan glukoz seviyesi $100 \mathrm{mg} / \mathrm{dl}$, serum kreatinin seviyesi 0,59 mg/dl, AST 46 U/L, ALT 17 U/L, LDH 1102 U/L, CRP 62 $\mathrm{mg} / \mathrm{L}$, D-dimer $954 \mathrm{mg} / \mathrm{L}$, lökosit sayısı 12.410 /mm3 (\%87,6 nötrofil; \%6,8 lenfosit), hemoglobin $11.9 \mathrm{~g} / \mathrm{dl}$ ve trombosit sayısı $258000 / \mathrm{mm}^{3}$ idi. Toraks bilgisayarlı tomografisinde (BT) her iki akciğerde, daha belirgin olarak sol tarafta ve alt loblarda yamalı buzlu cam dansiteli alanlar izlendi. Hasta COVID-19 ön tanısı ile interne edildi ve sonrasında Anti-HIV testi pozitif çıtı. Klinik, laboratuvar ve radyolojik incelemelere dayanarak hem COVID-19 hem de PCP tedavilerini olgumuza uyguladık. Sonunda iyileştikten sonra taburcu edildi. Pandemi sırasında sadece SARS-COV-2 değil, aynı zamanda akciğer enfeksiyonlarına neden olabilecek diğer infeksiyöz etkenler de göz ardı edilmemeli ve ayırıcı tanıda hepsi düşünülmelidir.

Anahtar kelimeler: COVID-19, HIV/AIDS, Pandemi, Pneumocystis jirovecii

DOI: 10.5798/dicletip.850549

Correspondence / Yazışma Adresi: Fethiye Akgül, Batman Bölge Devlet Hastanesi, Enfeksiyon Hastalıkları ve Klinik Mikrobiyoloji Kliniği, Batman, Türkiye e-mail: dr.fethiyeakgul@gmail.com 


\title{
An Incidentally Detected Case of AIDS Admitted with the Clinical Presentation of COVID-19 During the Pandemic
}

\begin{abstract}
Pneumocystis pneumonia (PCP) is a serious opportunistic infection caused by the fungus Pneumocystis jirovecii. However, the detection of severe acute respiratory syndrome coronavirus 2 (SARS-CoV-2) in the patients, following the recognition of pneumonia cases of unknown etiology on December 31, 2019, in Wuhan, China revealed a new type of coronavirus. The disease caused by that virus has subsequently been named COVID-19 (Coronavirus disease 2019) by the World Health Organization. In clinical practice, we encounter fever, shortness of breath, and radiological findings compatible with pneumonic infiltration in the bilateral lung parenchyma in both infections (PCP and COVID-19). As of May 11, 2020, the COVID-19 outbreak affected 198 countries and about 4.239.167 people on five continents. The World Health Organization declared it a pandemic on March 20, 2020. During the pandemic, COVID-19 should be considered first in every patient presented with fever and respiratory distress, and further examinations should be carried out. A 22-year-old male patient admitted with the complaints of fever and respiratory distress for two days during this period. On physical examination, his fever was $38,3^{\circ} \mathrm{C}$ with fine bilateral rales at lung auscultation. Results of the laboratory testing were as follows: the blood glucose level $100 \mathrm{mg} / \mathrm{dl}$, serum creatinine level 0,59 mg/dL, AST 46 U/L, ALT $17 \mathrm{U} / \mathrm{L}$, LDH 1102 U/L, CRP 62 mg/l, D-dimer 954 mg/L, leucocytes 12.410 /mm³ (87,6\% neutrophils; 6,8\% lymphocytes), hemoglobin $11.9 \mathrm{~g} / \mathrm{dL}$ and platelet count $258000 / \mathrm{mm}^{3}$. Thorax computed tomography (CT) demonstrated patched areas with frosted glass density in both lungs, more prominently on the left side, and in the lower lobes. The patient was admitted with a preliminary diagnosis of COVID-19, and then the Anti-HIV test was positive. Based on clinical, laboratory, and radiological examinations, we administered both COVID-19 and PCP treatments to our case. He was finally discharged after recovery. During the pandemic, not only SARS-COV-2, but also other infectious agents that may cause lung infections should not be ignored, and they all should be considered in the differential diagnosis.
\end{abstract}

Keywords: COVID-19 - HIV/AIDS - Pandemic - Pneumocystis jirovecii.

\section{GíRİ̧}

P. jirovecii'nin neden olduğu PCP bağışılklık sistemi baskılanmış hastalarda en sık görülen ve ciddi sonuçlara neden olabilen firsatçı enfeksiyonlardan biridir1. PCP epidemiyolojisi İnsan immün yetmezlik virüsü/ Akkiz immün yetmezlik sendromu (HIV/AIDS)'nun ortaya çıkması ile birlikte dramatik bir şekilde artış göstermiştir ${ }^{2}$. HIV ile iliş̧kili PCP çoğunlukla ateş, kuru öksürük ve nefes darlığı ile semptom vermektedir ${ }^{3}$. Çin'in Hubei Eyaleti, Vuhan Şehrinde, 31 Aralık 2019'da etiyolojisi bilinmeyen pnömoni vakaları bildirilmiştir. Yapılan epidemiyolojik çalışmalarda Vuhan'ın güneyindeki Vuhan Güney Çin Deniz Ürünleri Şehir Pazarı (farklı hayvan türleri satan bir toptan balık ve canlı hayvan pazarı) çalışanlarında kümelenme olduğu belirtilmiştir. Daha sonrasında COVID-19 olarak adlandırılan bu enfeksiyonun yaygın belirtileri; ateş, öksürük ve dispnedir. Radyolojik olarak bilateral akciğerde pnömonik infiltrasyon ile uyumlu bulgular tespit edilmektedir. Daha ciddi vakalarda ağır akut solunum yolu enfeksiyonu görülebilmektedir ${ }^{4}$. Hem PCP'nin hem de COVID-19'un klinik semptomları, fizik muayene bulguları birbirine benzemektedir. Her iki hastalık birlikte olabileceği gibi birbirine de karışabilmektedir 5 .

\section{OLGU}

Yirmi iki yaşında erkek hasta, ateş ve solunum sıkıntısı şikayetleri olması nedeniyle hastanemiz COVID polikliniğine yönlendirilmiş. Şikayetlerinin 2 gün önce başladığı öncesinde herhangi bir şikayetinin olmadığı öğrenildi. Soygeçmişinde ve özgeçmişinde özellik yoktu. Bilinen COVID-19 hastası ile temas öyküsü yoktu. Hastanın başvuru sırasında yapılan fizik muayenesinde ateş: $38,3{ }^{\circ} \mathrm{C}, \quad \mathrm{SPO} 2: \% 78$, solunum sayısı 28/dk, nabız $110 / \mathrm{dk}$ ve arteriyel kan basıncı 100/60 mmHg olarak ölçüldü. Fizik muayenesinde bilateral ralleri mevcuttu. İlk 
yapılan tetkiklerinde kan glukoz seviyesi: 100 $\mathrm{mg} / \mathrm{dl}$, serum kreatinin 0,59 mg/dl, AST:46 U/L, ALT:17 U/L, LDH:1102 U/L, CRP:62 mg/L, Ddimer: $954 \mathrm{mg} / \mathrm{L}$, lökosit sayısı:12.410/ $\mathrm{mm}^{3}$ (nötrofil:\%87,6, lenfosit:\%6,8) hemoglobin $11.9 \mathrm{~g} / \mathrm{dL}$, trombosit: $258000 / \mathrm{mm}^{3}$, prokalsitonin $0,07 \mathrm{ng} / \mathrm{mL}$, troponin 0.021 $\mathrm{ng} / \mathrm{mL}$ olarak sonuçlandı. PA AC grafisinde bilateral infiltrasyonlar vardı (Resim-1). Toraks BT'de; solda daha belirgin olmak üzere her iki akciğerde yaygın yamasal ve nodüler buzlu cam dansiteleri izlendi (Resim 2,3,4) ve COVID-19 pnömonisinin yaygın olarak bildirilen görüntüleme özellikleri mevcut idi. Hastadan COVID-19 örneği için nazal ve orofarengeal sürüntü alınarak interne edildi. Hastaya azitromisin, oseltamivir ve hidroksiklorokin tedavisi başlandı. Yatışının 2. gününden sonra ateşi olmadı. Ancak daha sonrasında hastanın kliniğinin kötüleşmesi ve PA AC grafisinde progresyon olması nedeniyle yoğun bakım ünitesine alındı. Tedavisine piperasilintazobaktam eklendi. Solunum sayısının artması SP02:\%68 olması ve solunumunun kötüleşmesi nedeniyle hasta elektif entübe edildi. İkinci kez SARS-CoV-2 numunesi alındı ve negatif olarak sonuçlandı. Hastanın toraks BT'sinin fırsatçı enfeksiyon da olabileceği düşünülerek hastadan Anti-HIV testi istendi ve pozitif olarak sonuçlandı. Tedavisine PCP ön tanısı ile trimetoprim-sulfametoksazol (TMP-SMX) i.v başlandı. CD4 hücre sayısı \%9,4, HIV RNA:358.000 kopya/ml, CMV IgM negatif, CMV Ig G pozitif idi. Entübasyonun beşinci gününde extübe edildi. Mycobacterium avium complex için azitromisin profilaksisi başlandı. COVID-19 ve PCP tedavisi tamamland.

Taburcu olurken kreatinin 0,63 mg/dl AST:54 U/L, ALT:51 U/L, LDH 423 U/L, CRP:5,4 mg/l, lökosit: $\quad 6670 / \mathrm{mm}^{3} \quad$ (nötrofil:\%87,7 lenfosit:\%7,9), hemoglobin $11.1 \mathrm{~g} / \mathrm{dL}$, trombosit:159000/ $\mathrm{mm}^{3}$ genel durumu iyi olan hasta, TMP-SMX tablet, azitromisin tablet ve elvitegravir+kobisistat+emtrisitabin+tenofovir alafenamid fumarate kombinasyonlu antiretroviral (ART) tedavi ile taburcu edildi.

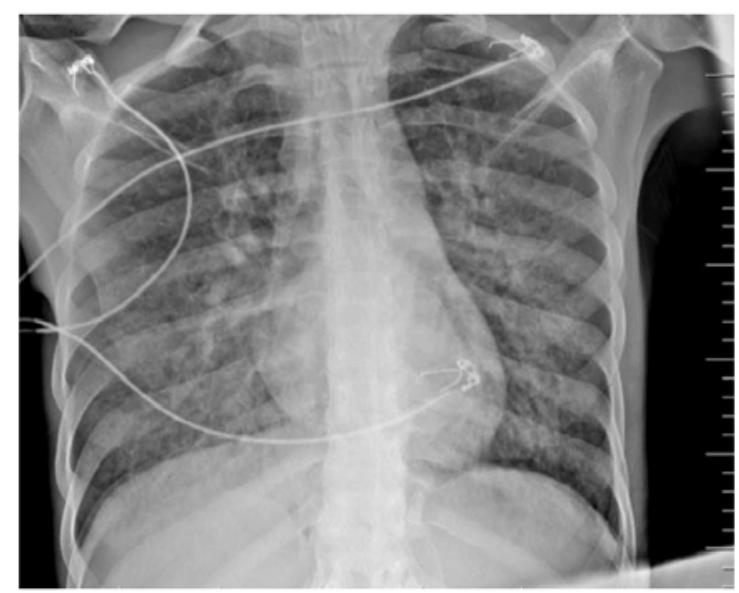

Resim 1: Bilateral yaygın infiltrasyonlar

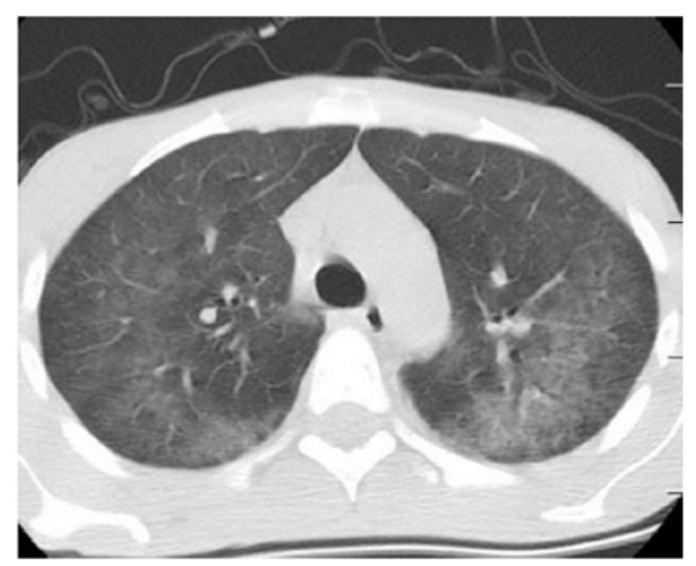

Resim 2: Solda daha belirgin olmak üzere her iki akciğerde yaygın yamasal ve nodüler buzlu cam dansiteleri

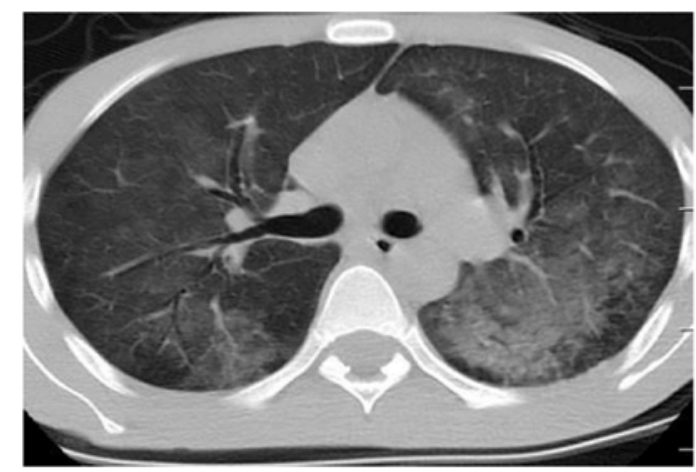

Resim 3: Solda daha belirgin olmak üzere her iki akciğerde yaygın yamasal ve nodüler buzlu cam dansiteleri 


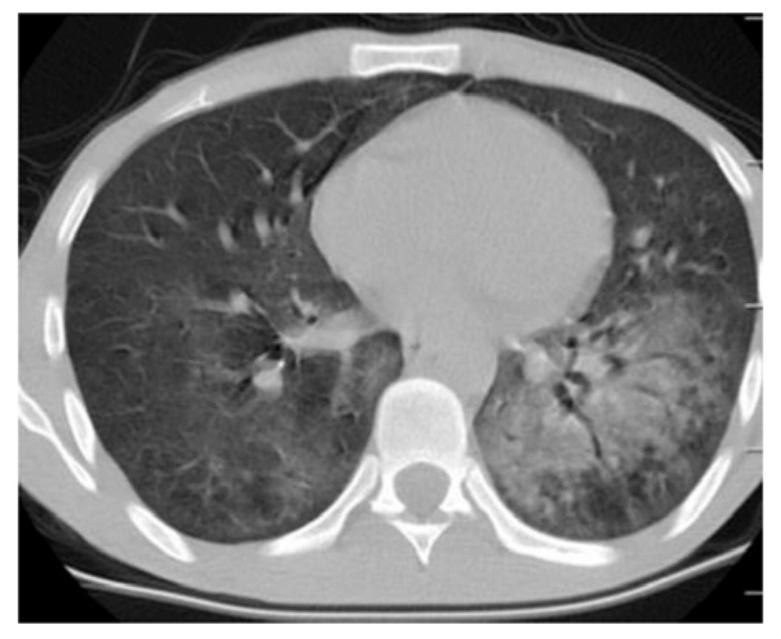

Resim 4: Solda daha belirgin olmak üzere her iki akciğerde yaygın yamasal ve nodüler buzlu cam dansiteleri

\section{TARTIŞMA}

Bağıșıklığı baskılanmış bireylerde PCP, hayatı tehdit eden bir enfeksiyondur6. PCP insidansı, profilaksi ve ART'nin yaygın kullanımıyla önemli ölçüde azalmıştır². Bu azalmaya rağmen HIV pozitif olduğundan haberi olmayan ya da tedavi almayanlarda CD4 hücre sayısı düşük olabileceğinden fırsatçı enfeksiyonların önde gelen nedenlerinden biri olmaya devam etmektedir ${ }^{3}$. Erişkinde PCP gelişimi için en önemli risk faktörü CD4 hücre sayısının 200/ $\mathrm{mm}^{3}$ den düşük olmasıdır ${ }^{7}$. PCP günler ile haftalar arasında ilerleyen ateş (\%80-100), öksürük (\%95) ve dispne (\%95) ile karakterizedir ${ }^{8}$. Hastalığın akut seyrettiği hastalarda fizik muayenede takipne, taşikardi bulunabilir ve nadiren ral duyulabilir ${ }^{9}$. COVID19'un klinik bulgularında da ateş, öksürük ve nefes darlığı vardır ${ }^{10}$. Olgumuz pandemi döneminde polikliniğimize ateş, öksürük, nefes darlığı şikayeti ile başvurmuş ve olası COVID-19 ön tanısı ile yatırılmıştır. Hastanın fizik muayenesinde PCP'nin de klinik bulgularından olabilen takipne ve taşikardi de vardı. Akciğer parankim hasarını gösteren LDH düzeyi PCP olgularının \%90'ında yüksek saptanır. Ancak PCP'ye özgül değildir. Genellikle > 500
mg/dL'nin üzerindeki LDH düzeyleri prognostik kabul edilir ${ }^{11}$. COVID-19'lu hastalarda yaygin laboratuvar bulguları arasında lenfopeni, yüksek aminotransaminaz düzeyleri, yüksek LDH seviyeleri ve yüksek inflamatuvar belirteçler bulunur ${ }^{10}$. Hastamızın laboratuvar bulgularında iki hastalığında ortak laboratuvar bulgularından olan lenfopeni, yüksek LDH vardı. COVID-19 tanısı nosofarengeal ve orafarengel sürüntüden alınmış olan örnekten gerçek zamanlı reverse transkripsiyon polimeraz zincir reaksiyonu (RT-PCR) gibi bir nükleik asit amplifikasyon testleri (NAAT) ile virüs RNA'sının özgül dizilerinin saptanması ve gerekli olduğunda nükleik asit dizi analizi yöntemi ile doğrulanması temeline dayanmaktadır ${ }^{4}$. Pneumocystis mikrobiyolojik olarak kültürde üretilemez, kesin tanı bronkoalveoler lavaj (BAL) sıvısı veya indüklenmiş balgam örneklerinde veya akciğer biyopsi örneklerinde mikroorganizmanın morfolojik olarak gösterilmesiyle konulmaktadır ${ }^{9}$. Ancak çoğu zaman klinik radyolojik ve laboratuvar tetkikleri sonucuna göre PCP'den şüphe duyarız ve ampirik tedavi başlarız ${ }^{12}$. PCP'de gözlenen tipik radyolojik bulgular, hastalık ilerledikçe homojenliği artan ve diffüz hale gelen bilateral interstisyel infiltratlardır ${ }^{13}$. Benzer radyolojik görüntüler COVID-19'da da görülmektedir ${ }^{14}$. Solunumla ilgili şikayetleri, ateşi ve radyolojik görüntülemesinde bilateral infiltrasyonu bulunan kişilerde ve bağışıklığı baskılanmış herhangi bir hastada PCP düşünülmelidir ${ }^{9}$. Ancak hastamı pandemi döneminde polikliniğimize başvurması ve HIV pozitifliğinden haberimiz olmaması nedeniyle öncelikli tanımız PCP değil COVID-19 olmuştur. COVID-19'in kesin tanısı her ne kadar RT-PCR ile konulsa da toraks BT bulguları olmasına rağmen RT-PCR testi negatif olabilmektedir ${ }^{15}$. Hastamızda da toraks BT COVID-19 ile uyumlu olduğu düşünülmüş ancak RT-PCR negatif olarak sonuçlanmıştı. 
COVID-19 ile benzer klinik, laboratuvar ve radyolojik semptomlarla ortaya çıkan pulmoner fırsatçı enfeksiyonlarda da olabilmektedir. COVID-19 tedavisinden fayda görmeyen hastalara yönelik ayırıcı tanı ve başlangıç antimikrobiyal tedavi sağlanmalıdır. PCP tedavisinde tercih edilecek ilk ajan TMPSMX'dür. Bizim hastamızda da öncelikli olarak COVID-19 düşünülmüş olup bu nedenle azitromisin ve hidroksiklorokin tablet rejim tedavisi verilmiş, takibinde klinik ve radyolojik bulgularında kötüleşme olması nedeniyle fırsatçı enfeksiyon açısından öncelikli olarak Anti-HIV testi istenmiş ve doğrulama sonucu beklenilmeden TMP-SMX tedavisi başlanmış olup pandemi döneminde başarılı bir hasta yönetimi olmuştur.

Sonuç olarak; bölgemizde HIV seroprevalansı yüksek olmasa da enfeksiyon hastalıkları açısından her zaman akılda tutulmalıdır. Pandemi döneminde COVID-19 ön tanısı ile yatan hastaların ayırıcı tanısında pnömoni yapan diğer etkenler de düşünülmeli ve göz ardı edilmemelidir. Özellikle HIV pozitif hastalarda fırsatçı enfeksiyonlar açısından da dikkatli olunmalıdır.

Etik Kurul Kararı: Hastadan onam formu alınmıştır.

Çıkar Çatışması Beyanı: Yazarlar çıkar çatışması olmadığını bildirmişlerdir.

Finansal Destek: Bu çalışma her hangi bir fon tarafından desteklenmemiştir.

Declaration of Conflicting Interests: The authors declare that they have no conflict of interest.

Financial Disclosure: No financial support was received.

\section{KAYNAKLAR}

1. Medrano FJ, Montes-Cano $\mathrm{M}$, Conde $\mathrm{M}$, et al. Pneumocystis jirovecii in general population. Emerg Infect Dis. 2005; 11: 245-50.

2. Huang L, Morris A, Limper AH, et al. ATS Pneumocystis Workshop Participants. An Official
ATS Workshop Summary: Recent advances and future directions in Pneumocystis pneumonia (PCP). Proc Am Thorac Soc. 2006; 3: 655-64.

3. Fujii T, Nakamura T, Iwamoto A. Pneumocystis pneumonia in patients with HIV infection: clinical manifestations, laboratory findings, and radiological features. Journal of infection and chemotherapy, 2007; 13: 1-7.

4. Türkiye Cumhuriyeti Sağlık Bakanlığı Halk Sağlığı Genel Müdürlüğü, Covıd-19 (2019-N Cov Hastalığı) Rehberi, Bilim Kurulu Çalışması, 14. Nisan.2020. Ulaşılabilirlik:

https://covid19bilgi.saglik.gov.tr/depo/rehberler/ COVID-19_Rehberi.pdf. [Erişim: 20 Mayıs 2020].

5. Blanco JL, Ambrosioni J, Garcia F, et al. COVID-19 in patients with HIV: clinical case series. The Lancet HIV, 2020; 7: 314-6.

6. Thomas CF Jr, Limper AH. Current insights into the biology and pathogenesis of Pneumocystis pneumonia. Nat Rev Microbiol 2007; 5: 298-308.

7. Benson CA, Kaplan JE, Masur H, et al. CDC; National Institutes of Health; Infectious Diseases Society of America. Treating opportunistic infections among HIV-infected adults and adolescents: recommendations from CDC, the National Institutes of Health, and the HIV Medicine Association/Infectious Diseases Society of America. MMWR Recomm Rep. 2004; 53: 1-112.

8. Kales CP, Murren JR, Torres RA, et al. Early predictors of in-hospital mortality for Pneumocystis carinii pneumonia in the acquired immunodeficiency syndrome. Arch Intern Med 1987; 147: 1413-7.

9. Walzer, PD, Smulian, AG. Pneumocystis species. In: Mandel, GL, Bennett, JE, Dolin, R, eds. Mandel, Douglas and Bennett's Principles and Practice of Infectious Disease. 6th ed. Philadelphia, PA: Elsevier Churchill Livingstone; 2005: 3080-94.

10. Guan WJ, Ni ZY, $\mathrm{Hu} \mathrm{Y}$, et al. Clinical Characteristics of Coronavirus Disease 2019 in China. N Engl J Med 2020; 382: 1708-20.

11. Esteves F, Lee C-H, De Sousa B, et al. $(1 \rightarrow 3) \beta$-dglucan in association with lactate dehydrogenase as biomarkers of Pneumocystis pneumonia (PcP) in HIV-infected patients. Eur J Clin Microbiol. İnfect Dis. 2014; 33: 1173-80. 
12. Huang L, Cattamanchi A, Davis JL, et al. HIVassociated Pneumocystis pneumonia. Proceedings of the American Thoracic Society, 2011; 8: 294-300.

13. Thomas CF Jr, Limper AH. Pneumocystis pneumonia. N Engl J Med. 2004; 350: 2487-98.

14. Wong HYF, Lam HYS, Fong AH, et al. Frequency and Distribution of Chest Radiographic Findings in COVID-19 Positive Patients. Radiology 2020; 296: 72-8.

15. Tao Ai, Zhenlu Yang, Hongyan Hou, et al. Correlation of Chest CT and RT-PCR Testing in Coronavirus Disease 2019 (COVID-19) in China: A Report of 1014 Cases . Liming Xia Radiology 2020; 296: 32-40. 